\title{
THE LEGAL POSITION OF LECTURER AT UNIVERSITY WHICH INCORPORATED AS FOUNDATION IN INDONESIA
}

\author{
Surya Nita \\ Faculty of Law Universitas Andalas Indonesia \\ Email: suryanita.fhunpab@gmail.com
}

\begin{abstract}
The Foundation is Organizing Body of Universities carry out the functions and purposes of workers hired as a lecturer in providing formal educational services to students. Lecturer profession specialized field of work with the principle of upholding the professionalism of legislation, laws, codes of conduct, as well as religious values and ethics. The issue of this article as follows: (1) How does the organization of University carried out by people in Indonesia ?; (2) How does the position of lecturer in University which incorporated as foundation in Indonesia ?; (3) How is the regulation on legal position of lecturer in University which incorporated as foudation in the future?. Juridical empirical research methods in the field of law aims to completely describe the characteristics of certain situation, private or group behavior. The research use sample purposive sampling that is case of lecturer with Foundation in Industrial Court of Yogyakarta and Medan. The research use qualitative descriptive for data analysis to describe legal position of lecturer in University which incorporated as Foundation in Indonesia. Based on result, the management model of University is Private University for university management. The rights and obligation of Private University management rely on the Foundation. Autonomy, accountable, fair and transparent that are regulated on the Law Number 12 of 2012 on Higher Education can not well implemented due to the Foundation as legal body has the rights and obligation that effect any activities of University which incorporated as Foundation in Indonesia. Lecturer, as a professional, is appointed in accordance with regulation in using work relationship based on labor agreement contains the terms of employment rights and obligations of the parties with the principle of equality based on the Law Number 13 of 2003 on Employment. The use of the term mutual agreement is not known in Employment Act. In the future, in order to meet the ground of Pancasila Justice, the legal relationship between the lecturers and the foundation is a relationship based on the principles of Pancasila Justice provides legal protection to the weak position because it ensures the balance of rights and obligations of the parties.
\end{abstract}

Keywords: Legal Position of Lecturer, University which incorporated as Foundation

\section{A. INTRODUCTION}

The Foundation is the organizer of University in exercising its functions and the aim employing lecturer as workers to provide formal educational services to students. The parties to the employment relationship in Private University is the foundation with the lecturer. Rector or the Dean of the college as a manager acting for and on behalf of the foundation is 
also a party to the employment agreement with the lecturer. Legal relationship between the workers and the employer is work relationships. The Foundation is giving jobs and who ruled this category as stipulated in Article 50 of the Law Number 13 of 2003 on Employment. Employment relationship occurs because of the labor agreements between employers and workers.

Labor relations of lecturer at Private University, once using labor agreement according to the Employment Law, contracts in general, and also be able to use the Decree of the Foundation, as well as the Rector Decree and the Decree of the Dean. Lecturer in employment relations can be done with the foundation and managers. Lecturer status consists of Foundation Lecturer, State Lecturer seconded called the DPK Lecturer, University Lecturer and Lecturers are not fixed (contract). This condition describes the shape of different lecturers working relationship with labor relations in general and differ in determining the rights and obligations. The Law Number 14 of 2005 on Teachers and Lecturers and the Law Number 12 of 2012 on Higher Education, in addition to regulating the lecturer at the State University (PTN), both conditions are also set about a lecturer at the Private University (PTS). In reality, supervisor on employment of PTS lecturer is not executed because PTS has not report the work agreement to Labor Office. This may be due in the Law Number 14 of 2005 on Teachers and Lecturers has not mention of surveillance systems of lecturers working relationship with the foundation as an organizer. If there is a problem of work who can help resolve labor relations problems are resolved according to the provisions stipulated in the Law Number 2 of 2004 on Settlement of Industrial relations disputes.

Given the various conditions and the legal issues that arise after a law regulation established and declared as valid, it is necessary to develop a plan thought the arrangements made in an integrated manner, in this case between the Law Number 14 of 2005 on Teachers and Lecturers, the Law Number 13 of 2003 on Employment, the Law Number 12 of 2012 on Higher Education and Law Number 28 of 2004 on Amendment of Law Number 16 of 2001 on the Foundation. So we need a research and depth analyzes over the principles of formation of the good legislation, in an effort to produce legislation that has the characteristics of resilient and sustainable. A law can accommodate and regulate various legal issues, for a long period of time (Yuliandri, 2010: p 11).

Legislation associated with the lecturers regulated in Law Number 14 of 2005 on Teachers and Lecturers, Law Number 12 of 2012 on Higher Education, Law Number 13 of 2003 on Employment performed legal issues management on lecturers at PTS and Law Number 28 of 2004 on Amendment of Law Number 16 of 2001 on the Foundation. Found the main legal issues on lecturers working relationship with the foundation. Thus formulated in table 1.1 as follows:

Table 1.1. Legal Issue on Lecturer Position at Private University 


\begin{tabular}{|c|c|c|}
\hline No & Theoretical issues & Practical issues \\
\hline 1. & $\begin{array}{l}\text { Lecturer profession is a field of specialized work } \\
\text { carried out by the principles of professionalism } \\
\text { upheld the legislation, laws, and codes of } \\
\text { conduct, as well as religious values and ethics of } \\
\text { Article } 7 \text { of Law No. } 14 \text { Year } 2005 \text {. }\end{array}$ & $\begin{array}{l}\text { Lecturer in Employment Relations } \\
\text { with the Foundation for anyone to } \\
\text { use the system of employment, } \\
\text { contracts, in general, Foundation } \\
\text { Decree, Rector Decree / Dean } \\
\text { Decree, statutes of universities. }\end{array}$ \\
\hline 2. & $\begin{array}{l}\text { Rights and Obligations Lecturer by Article } 51 \text { - } \\
60 \text { of Law No. } 14 \text { of } 2005 .\end{array}$ & $\begin{array}{l}\text { Positions that not balanced } \\
\text { between the lecturer with the } \\
\text { Foundation may cause problems } \\
\text { in determining the rights and } \\
\text { obligations, labor protection, } \\
\text { social security and welfare of the } \\
\text { lecturers have not been up as } \\
\text { stipulated in the law. }\end{array}$ \\
\hline 3. & $\begin{array}{l}\text { Wage system according to Article } 52 \text { paragraph } \\
\text { (1) of Law No. } 14 \text { of } 2005 \text { income above the } \\
\text { minimum living needs as referred to in } 51 \\
\text { paragraph (1) letter a comprise basic salary, } \\
\text { allowances attached to salaries, other income in } \\
\text { the form of the professional allowance, } \\
\text { functional allowance, special allowance, } \\
\text { allowance of honor, as well as the beneficiaries } \\
\text { additional related assigned duties as a lecturer on } \\
\text { the basis of achievement awards. Faculty } \\
\text { workload of Article } 72 \text { paragraph (2) worth } 12 \\
\text { credits and a maximum of } 16 \text { credits. }\end{array}$ & $\begin{array}{l}\text { Article } 92 \text { paragraph (1) of Law } \\
\text { No. } 13 \text { of } 2003 \text { on Employers to } \\
\text { structure and scale of wages by } \\
\text { paying attention to class, position, } \\
\text { a length of employment, } \\
\text { education, and competency. } \\
\text { Minister of Manpower Regulation } \\
\text { No. PER-01 / MEN / } 1985 \text { About } \\
\text { General Pattern Collective Labor } \\
\text { Agreement (CLA) said the wage } \\
\text { system includes salary structure, } \\
\text { such as net pay, base salary, plus } \\
\text { allowances, granting the premium } \\
\text { associated with work productivity. } \\
\text { The wage increase which can base } \\
\text { on the percentage increase in the } \\
\text { consumer price index or physical } \\
\text { needs at least once a year, work } \\
\text { performance, ability or the } \\
\text { company's development, tenure, } \\
\text { and bonuses, gratuities, other } \\
\text { benefits if it will be given. } \\
\text { In the calculation of hourly wages } \\
\text { in monthly salary = 1/173 x } \\
\text { monthly salary. }\end{array}$ \\
\hline 4. & $\begin{array}{l}\text { Employment occurs because of their } \\
\text { employment contracts and collective agreements } \\
\text { Article } 1 \text { paragraph } 7 \text { of Law No. } 14 \text { of } 2005 .\end{array}$ & $\begin{array}{l}\text { In the provisions of the labor law } \\
\text { employment relationship born } \\
\text { because of the agreements, the } \\
\text { Collective Labor Agreement } \\
\text { which formed the unions and } \\
\text { company unions, Corporate } \\
\text { Regulation. In the legislation does } \\
\text { not mention the teachers and }\end{array}$ \\
\hline
\end{tabular}




\begin{tabular}{|c|c|c|}
\hline & & $\begin{array}{l}\text { lecturers Foundation regulations } \\
\text { in the Articles of Association By } \\
\text { laws or Statutes Private College as } \\
\text { one of the company's rules } \\
\text { governing labor relations which } \\
\text { contain rights and obligations of } \\
\text { lecturers. }\end{array}$ \\
\hline 5. & $\begin{array}{l}\text { Lecturer working relationship through the } \\
\text { Employment Agreement and the collective labor } \\
\text { agreement is a written agreement Article } 1 \\
\text { paragraph } 7 \text { of Law no. } 14 \text { of } 2005 \text {. }\end{array}$ & $\begin{array}{l}\text { Lecturer on labor relations } \\
\text { consists of labor agreements, and } \\
\text { the decree, which issued by the } \\
\text { Foundation, Rector, and Dean. }\end{array}$ \\
\hline 6. & $\begin{array}{l}\text { Lecturer status consists of Lecturers and } \\
\text { Variable Article } 48 \text { of Law No. } 14 \text { of } 2005 .\end{array}$ & $\begin{array}{l}\text { Full-time Foundation, Fulltime of } \\
\text { Private University lecturer, } \\
\text { University Lecturer and Variable } \\
\text { University lecturer. }\end{array}$ \\
\hline 7. & $\begin{array}{l}\text { Lecturers given the right to associate in } \\
\text { professional organizations / scientific } \\
\text { professional organization of Article } 51 \\
\text { paragraph (1) letter g of Law no. } 14 \text { of } 2005\end{array}$ & $\begin{array}{l}\text { Private Lecturer Professional } \\
\text { Organization has not yet formed, } \\
\text { so that in determining the content } \\
\text { of the work agreement, the rights } \\
\text { professor as professional } \\
\text { educators and scientists } \\
\text { guaranteed in the legislation. The } \\
\text { function of trade unions in } \\
\text { protecting workers' rights are not } \\
\text { regulated in the Law on Teachers } \\
\text { and Lecturers as stipulated in Law } \\
\text { No. } 13 \text { of } 2003 \text { on Employment. }\end{array}$ \\
\hline 8. & $\begin{array}{l}\text { Lecturers must comply with the Code of Ethics } \\
\text { lecturer. }\end{array}$ & $\begin{array}{l}\text { Lecturer in performing } \\
\text { professional duties must have a } \\
\text { code of ethics formulated by } \\
\text { professional organizations, but in } \\
\text { practice, the code of ethics have } \\
\text { not included teachers existing } \\
\text { principles of professionalism. }\end{array}$ \\
\hline 9. & $\begin{array}{l}\text { The government, local governments, } \\
\text { communities, professional organizations, and } \\
\text { higher education or unit must provide protection } \\
\text { for lecturers in carrying out their duties } \\
\text { following forms of protection as legal protection, } \\
\text { the protection of the profession, as well as } \\
\text { occupational safety and health protection of }\end{array}$ & $\begin{array}{l}\text { In the fight for their rights lecturer } \\
\text { should have a professional } \\
\text { organization as a lecturer in the } \\
\text { protection of fundamental rights } \\
\text { of law, the protection of the } \\
\text { profession as well as occupational } \\
\text { safety and health protection are } \\
\text { not to be taken up by the }\end{array}$ \\
\hline
\end{tabular}




\begin{tabular}{|c|c|c|}
\hline & Article 75 of Law no. 14 of 2005. & $\begin{array}{l}\text { Foundation as a legal entity } \\
\text { organizing education. }\end{array}$ \\
\hline 10. & $\begin{array}{l}\text { Coaching, professional development of lecturers } \\
\text { include coaching, professional development, and } \\
\text { career. regulated in Article } 69 \text { - } 74 \text { of Law No. } \\
14 \text { of } 2005\end{array}$ & $\begin{array}{l}\text { The law does not mention } \\
\text { surveillance system working } \\
\text { relationship with the organization } \\
\text { as a faculty organizer. Is it just } \\
\text { DIKTI through Kopertis, BAN-PT } \\
\text { or the Department of Labor, } \\
\text { employment in case of problems } \\
\text { which can help solve through } \\
\text { bipartite, tripartite, even the } \\
\text { settlement of labor disputes. }\end{array}$ \\
\hline 11. & $\begin{array}{l}\text { In Employment Act made any working } \\
\text { relationship of the parties shall be recorded or } \\
\text { reported to the workforce as a database to } \\
\text { determine what load the implementation of the } \\
\text { employment relationship rights and } \\
\text { responsibilities under the normative reasons. }\end{array}$ & $\begin{array}{l}\text { In the Law on Teachers and } \\
\text { Lecturers do not cover the } \\
\text { obligations of the Foundation or to } \\
\text { register to the department } \\
\text { manager workforce working } \\
\text { relationship is created, so the } \\
\text { guidance and supervision are not } \\
\text { clear. }\end{array}$ \\
\hline 12. & $\begin{array}{l}\text { In Article } 90 \text { paragraph (1) jo. Article } 185 \\
\text { paragraph (1) of Law No. } 13 \text { of } 2003 \text { on } \\
\text { Manpower if the company does not pay the } \\
\text { provincial minimum wage or salary payment } \\
\text { delays according to UMP workers/ laborers } \\
\text { company may be liable. }\end{array}$ & $\begin{array}{l}\text { The provisions of Article } 51 \\
\text { paragraph (1) letter a mention } \\
\text { professors earn above the } \\
\text { minimum living needs and social } \\
\text { welfare, but in sanctions for the } \\
\text { organizers in Article } 79 \text { does not } \\
\text { mention Article } 52 \text { paragraph (1) } \\
\text { letter a being violated. Penalties in } \\
\text { Law } 14 \text { of } 2005 \text { does not use } \\
\text { criminal sanctions or force rules. }\end{array}$ \\
\hline 13. & $\begin{array}{l}\text { Management of Higher Education conducted a } \\
\text { foundation governed by Article } 62 \text { of Law No. } \\
12 \text { of } 2012 \text { on Higher Education as follows: }\end{array}$ & $\begin{array}{l}\text { Foundations can determine their } \\
\text { form of employment relationship } \\
\text { lecturer based autonomy. } \\
\text { Foundation in the management of } \\
\text { PTS should implement the } \\
\text { principle of university autonomy } \\
\text { obligation in making employment } \\
\text { contracts and statutes of the }\end{array}$ \\
\hline
\end{tabular}


| $\mid$ college.

Source : processed from legislation

Based on the background above, there are three main issues as follow :

1. How does the organization of University carried out by people in Indonesia?;

2. How does the position of lecturer in University which incorporated as foundation in Indonesia? ;

3. How is the regulation on legal position of lecturer in University which incorporated as foudation in the future?

The theory is used to answer the problem is the theory of legal body discuss the theory of wealth aim of Brinz, organ theory, and the theory of concession where the legal body for a collective of human beings is because it was created by a particular authority. Theory of justice of John Rawls, a value that embodies a balance between the parts in unity, the common goals. While the theory of the formation of legislation discusses legislative theory of Otto et al.

Legal body (Habib.Adjie, 2008 14) is an organization, agency, group, institutions, or property, established or confirmed by the law intended as holders of rights, powers, obligations, property, tasks, status, privileges himself in principle, separate from those of the human individual, has a board that represents and runs the interests of legal body and interests of its members, so that the legal body can claim / sue or be sued before the court, in addition can also be the victim of a crime that even in understanding, legal body can also do a crime and convicted criminal (Munir. Fuady, 2013:168-169).

Foundation as Univeristies organizer in Indonesia created by the Government as a legal body aims to carry out its function of formal education as stipulated in Law Number 12 of 2012 on Higher Education. Foundation as organizers of Higher Education aims to promote education, including in the social goals of humanity, regardless of educational donation receipt, or in other words source of income, but the most important is the goal. Educating the nation, promote education and or improve the quality of education as the goal of the establishment of the foundation in the field of education. The Foundation undertakes the function as Universities organizer has a constitution and domestic laws. The foundation has 
Higher Education shall make University Statute. The legal basis for the establishment of the Statute of the Higher Education is Law Number 12 of 2012 on Higher Education Article 60 paragraph (5) Higher Education shall have the Statute.

Theory of Justice by John Rawls, a value that embodies a balance between the parts in unity, between the objectives of the common objectives. Based on the consideration and approval of the principles of justice which is called 'justice as fairness', emphasized the need upheld two principles, namely the principles of freedom and equality of citizens and the principle of protection for the needy that economic circumstances are not favorable in social stratification, which is structurally unjust ( Teguh Prasetyo and Abdul Halim Barkatullah, 2012: 329-330). According to Rawls unjust to sacrifice the rights of one or several people just for the sake of greater economic benefits for society as a whole. This attitude is precisely contrary to justice as fairness, which requires the principle of equal freedom as the basis of social welfare settings.

Program that justice dimension of citizenship shall observe two principles of justice. First, give the same rights and opportunities on the basis of the most extensive as wide as equal freedom for everyone. Second, is able to reorganize the socio-economic gap that occurs, so that it can provide reciprocal benefits for everyone, from the group of lucky or unlucky (Teguh. Prasetyo, and Abdul Halim Barkatullah, 2012: 329- 330).

The theory of the formation of laws that can be used as a comparison in measuring the quality of the formation of law in Indonesia is a legislative theories of Otto, et al in the Yuliandri that distinguish legislation theory into three categories:

1. Theories on the lawmaking process 'itself';

2. Theories on the social effect of laws that are enacted;

3. Theories on internationally driven law reform.

This thought tried to steer the theory of the formation of legislation to the social-legal concept of real legal certainty (Yuliandri, 2010: 26-27).

\section{B. RESEARCH METHODS}

This type of research is juridical empirical research in the field of law that aims to describe in full the characteristics or traits of a particular condition, personal behavior and the behavior of the group to formulate the problem. The nature of this research os descriptive research. 
Descriptive research is intended to provide data specifically about humans (PTS Lecturer), situation or other symptoms. Where the intention is to obtain data on the relationship between one symptom with another.

The data the source used by using a sample case through purposive sampling lecturer in the PTS through case law in the Industrial Court in Yogyakarta and Medan. Data collection instruments as follows done collecting the material, then held organizing systematically selected and arranged to facilitate in analyzing the data obtained from the research literature, so as to obtain a comprehensive picture of the rules of law relating to research problems. The data obtained from the field through structured interviews and rechecked again over completeness of answers.

Analysis process or interpretation of the results of the research was descriptive. With a qualitative approach to the primary data and secondary data (Zainuddin Ali, 2011: 107). Includes descriptive content and positive structure that is an activity undertaken to determine the content or the meaning of the rule of law referenced assessment. In this study, analysis of the data is not out of the scope of the sample is specifically based on the theory of general concepts applied to describe a set of data, or show a comparison or relationship data set to another set of data (Bambang Sunggowo, 1997: 38). Qualitative analysis found the legal position of a lecturer at the University which incorporated as Foundation obtained from the research literature and field research to be concluded as an answer to the problems studied by the inductive method is a process of reasoning that departs from a sentence specific question to arrive at a conclusion which will be able to answer some general statements (Soetandyo. Wignjosoebroto, 2011: 99).

\section{Chart 1.1 Schemes of Empirical Juridical Research Process}

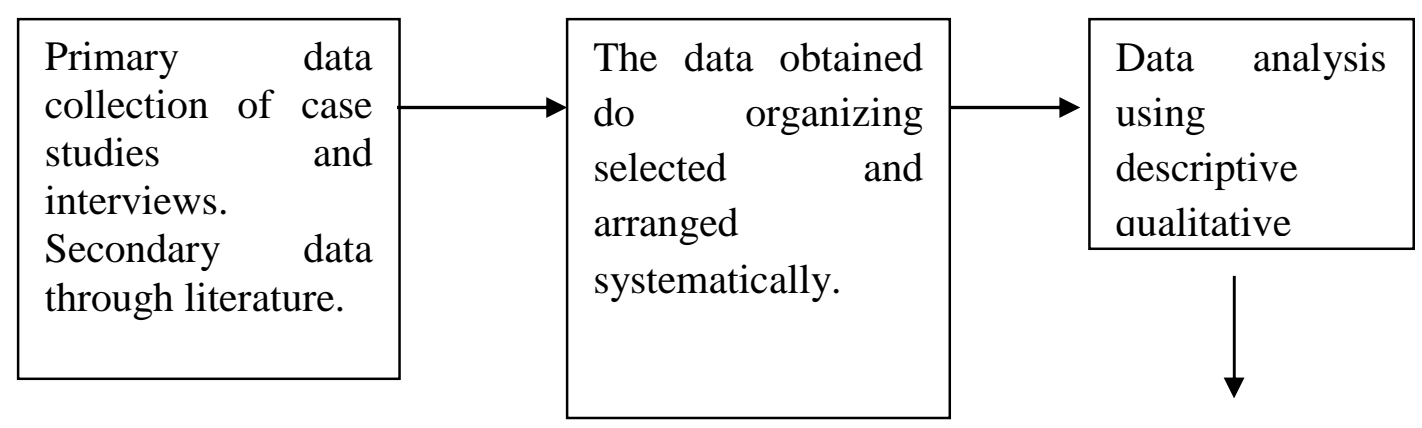

\begin{tabular}{|c|c|c|}
\hline & & $\begin{array}{l}\text { Conclusions drawn in response to the } \\
\text { problems studied by the inductive } \\
\text { method is a process of reasoning that }\end{array}$ \\
\hline 709 & Yustisia. Vol. 5 No. 3 September-Desember 2016 & $\begin{array}{l}\text { departs from Tha Le priticitibarof Lsentence } \\
\text { question to arrive at a conclusion that } \\
\text { will be able to answer some general } \\
\text { statements. }\end{array}$ \\
\hline
\end{tabular}




\section{DISCUSSION}

Lecturer consists of State lecturers seconded to the foundation called DPK, foundation lecturer, part-time lecturers, so that the status of labor relations there are subjected to regulations for c ivil servants DPK lecturers, for lecturers remain subject to the Law Number 13 of 2003 for compliance with the rules as stipulated in the law, part-time lecturers are generally subject to the agreement because it does not meet all of the elements in a working relationship that is their command, their jobs, their wages and their working time.

This has an impact on the fulfillment of the rights and obligations of the parties depends on the agreement of the parties or open consensus. In a surveillance system working relationship lecturer with the foundation and the university is not running as its function is only a formality to see the agreements contained in the creation of NIDN as required under the rules of registration, but in the implementation of the rights and obligations of lecturers are not monitored on an ongoing basis by the Ministry of Research and Technology of Higher Education only on promotion and the provision of lecturers certification is limited to only the administrative process. System of labor inspection are also not functioning properly due to the reasons of personnel absence of a complaint, it is considered that there are no problems in labor relations professor at the college incorporated foundation for unreported employment agreement of the parties, if there are problems then held a settlement out of court through mediation, if the settlement is not reach, then it will be submitted to the court settlement of industrial relations.

The vagueness of work relationship with the College lecturers incorporated the Foundation the opportunity to avoid the application of rights and obligations in the employment agreement as stipulated in the Employment Law and the Law on Teachers and Lecturers. In the provisions of Law Number 14 of 2005 on Teachers and Lecturers are not regulated professional certification agency that sets standards of competence a lecturer with setting the minimum standards that must be given to the lecturers at the College of form of foundations as a form of protection for lecturers as professionals, so it will have an impact on the provision of wage standards in accordance with lecturer's workload as stipulated in Article 72 of Law Number 14 of 2005 on Tri Dharma of University in Law Number 14 of 2005 on Teachers and Lecturers, lecturer recognition evidenced by a certificate of educators. 
Stipulation of the legal position of a lecturer at the University which incorporated as foundation in Indonesia in the future is the need to meet the ground of Pancasila justice, as stipulated in the basic foundation of the state as a theoretical basis in resolving the legal issues, especially the legal position of a lecturer at University which incorporated as foundation in Indonesia. In terms of finding the essence of the ground of Pancasila justice that a legal relationship between lecturer and the university form of foundations should be based on the values of belief in one God, humanity just and civilized, the unity of Indonesia, Democracy led by wisdom in deliberation and representation, Social justice for all the people of Indonesia. Beads of conception of the Pancasila, or five principles as well as the five principles in the regulation of the formation of law.

So that the legal relationship between the lecturers and the foundation is a relationship based on the principles of Pancasila justice by providing legal protection more to the weak position because to ensure the balance of rights and obligations of the parties to provide compensation will unbalance the top position of the sub-ordinate between lecturers and university which incorporated as foundation. Legal relationship that will be created in the Pancasila principles of justice as stipulated in the law is legal certainty purpose, usefulness and fairness to the parties in establishing relations law. That any agreement should be conducted honestly or in good faith based on the principle of trust of the parties in making agreements, especially the agreement in the legal relationship between lecturers and foundations. The obedience in implementing rights and obligation to do an action for all perties in the ground of Pancasila justice.

\section{CLOSING}

\section{Conclusion}

Based on results and discussion, there are conclusion as follow :

a. That model of organization of higher education that conducted by communities in Indonesia is University which incorporated as Foundation, known as PTS simply as managers of higher education all the rights and obligations of the management is in the foundation, so the implementation of autonomy, accountable, transparent and fair, as set out in Law Number 12 of 2012 on Higher Education can not be implemented as well as possible for the foundation to the authority as the foundation which has the right and obligation of course affect all activities of university which incorporated as foundation in Indonesia. 
b. That the legal position of a lecturer at the University which incorporated as foundation in Indonesia are lecturers as professionals in higher education who are appointed in accordance with the legislation using a working relationship based on labor agreement or a collective agreement that includes the terms of employment and the rights and obligations of the parties with the principle of equality by legislation namely Law No. 13 of 2003 on Employment. The use of the term collective agreement no longer known in Law Number 13 of 2003 that is used is the Collective Work Agreement, that this rule does not adjust the development of existing laws and regulations.

c. That stipulation of the legal position of a lecturer at the University which incorporated as foundation in Indonesia in the future is the need to meet the ground of Pancasila justice, so that the legal relationship between the lecturers and the foundation is a relationship based on the principles of Pancasila justice by providing legal protection to the weak position due to ensure the balance of rights and obligations of the parties.

\section{Recommendation}

There are reccomendations as follows:

a. That rules model of higher education at university in Indonesia through the foundation should be the responsibility of the state in providing and guaranteeing education for future generation of nation. So that in the future there needs to be improvement in the management of higher education, the state is responsible for providing compensation in the form of foundations Higher Education in Indonesia to be taken over by the state. So that the foundation can remain focused perform its function as a nonprofit institution that run social function in accordance with the Foundation Law Regulation.

b. That the legal position of a lecturer, as professionals, should have institution of certification lecturers profession. Where this institution has the authority to create professional standards lecturer by issuing a certificate, the certificate is valid for 5 years and can be renewed with the enhancement of competence in performing its function as professionals who carry out the tri dharma college. So there needs to be a revision of the Law on Teachers and Lecturers specifically for lecturers for the development of governance is the Research and Technology Ministry of Higher Education in higher education not combined again with the Ministry of Education and Culture.

c. That there should be special arrangements for lecturers in Indonesia by lecturer Law as a guide for lecturers in Indonesia. In this kind law, lecturer has its particularity consisting of State University lecturer divided on lecturers, University Lecturer and part-time lecturers, 
while the Private University has its lecturer called Kopertis (DPK), Foundation lecturer and part-time lecturers that needs to be regulated from the employment relationship, rights and obligations, the supervisory structure, professional organization, welfare lecturers, professional certification institution for lecturers, not only related to the requirements to become a lecturer, but also related to standardization regarding the rights and obligations of lecturers with more attention to the condition of progress of the lecturers who focus on the development of education in Indonesia through lecturer Law in Indonesia. Lecturer is the teacher of the nation that is responsible to educate, and to prosper the nation's future through their devotion. In the rule of law, lecturers in Indonesia no longer recognize as State PNS Lecturer (Pegawai Negeri) or Private Lecturer (Swasta), but all the lecturers in Indonesia became state lecturer as giving tribute to nation educators nation which carries out the nation's intellectual life and welfare of the people through education.

\section{E. ACKNOWLEDGMENTS}

Praise God Almighty for the implementation of Doctoral Dissertation Research in 2016 with the title Legal Status Lecturer In Higher Education Legal Entity Foundation in Indonesia. I am grateful to the Ministry of Research and Technology and Higher Education of the Republic of Indonesia, which has funded research and programs of continuing education doctorate, Graduate Doctor of Law, University of Andalas where continuing education, counselors dissertation Promoter and Copromotor, Party Kopertis Region I North Sumatra facilitating the administration of the doctoral program, and University Development Panca Budi through LPPM UNPAB who have supported completing a doctoral program.

The study conducted by interviewing the Ministry of Labor of the Republic of Indonesia, Medan City Employment Agency, the Chief Justice Dr. Supandi, SH, MHum Supreme Court of the Republic of Indonesia, the Industrial Relations Court of Medan and PHI Yogyakarta to get answers from the formulation of the problem in this study. Hopefully, this research can be useful for Lecturers in Higher Education Legal Entity Foundation in Indonesia, practitioners, and society in general.

\section{BIBLIOGRAPHY:}

\section{Book}

Adjie. Habib, 2008, Status Badan Hukum Prinsip Prinsip dan Tanggung Jawab Sosial Perseroan Terbatas, Mandar Maju.

Ali. Zainuddin, 2011, Metode Penelitian Hukum, Sinar Grafika, Jakarta 
Fuady. Munir. 2013. Teori-Teori Besar (Grand Theory) Dalam Hukum. Jakarta: Kencana Prenada Media Group.

Prasetyo Teguh, Abdul Halim Barkatullah. 2012. Filsafat, Teori, \& Ilmu Hukum. Jakarta: Rajawali Pers.

Sunggowo. Bambang. 1997. Metode Penelitian Hukum. Jakarta: PT RajaGrafindo Persada.

Wignjosoebroto. Soetandyo. 2011. Peenelitian Hukum dan Hakikatnya Sebagai Penelitian Ilmiah, Dalam buku Metode Penelitian Hukum Konstelasi dan Refleksi. Jakarta: Buku Obor.

Yuliandri. 2010. Asas-Asas Pembentukan Peraturan Perundang-Undangan yang Baik Gagasan Pembentukan Undang-Undang Berkelanjutan. Jakarta: RajaGrafindo Persada.

\section{Regulation}

KUHPerdata terjemahan Prof. R Subekti, SH dan R. Tjitrosudibio, B.W. (Kitab UndangUndang Hukum Perdata), Staatsblad 1847 No. 23.

Law Number 13 of 2003 on The Labour

Law Number 2 of 2004 on The Dispute Settlement of The Industrial Relation

Law Number 28 of 2004 on The Amandement of Law Number 16 of 2001 on The Foundation

Law Number 14 of 2005 on Teacher and Lecturer

Law Number 12 of 2012 on The Higher Education 